удк 164(045)

\title{
ЛОГІСТИКА ЯК ІНСТРУМЕНТ ПІДВИЩЕННЯ КОНКУРЕНТОСПРОМОЖНОСТІ ПІДПРИЕМСТВА
}

\author{
Бессонова А.В., Лавренюк С.М., Середницька Л.П. \\ Вінницький торговельно-економічний інститут \\ Київського національного торговельно-економічного університету
}

DOI: https://doi.org/10.32839/2304-5809/2018-12-64-134

В статті досліджено логістику як інструмент підвищення конкурентоспроможності підприємства в сучасних умовах господарювання. Проаналізовано особливості впливу логістичних витрат на ефективність фуннціонування логістичної системи в умовах фрункціонування розвиненої економіки. Визначені та обгрунтовані сучасні економічні інструменти, підвищення ефективності логістичних процесів та отримання такого економічного ефекту, як скорочення витрат і часу у сфрерах виробництва та обігу.

Ключові слова: логістика, витрати, ефективність, логістичний менеджмент, підприємство, логістична система, конкурентоспроможність.

Постановка проблеми. У зв'язку зі зміною 1 процесів зовнішнього середовища фонкціонування підприємств необхідним стає застосування та впровадження новітніх методів у їх управлінні. При цьому, недостатньо, щоб ефективними були окремі управлінські рішення, необхідно прагнути до ефективності ведення господарської діяльності в цілому. Це потребує поглибленого вивчення сучасних методів управління, зокрема, логістики, яка базується на традиційних підходах і є рушійним елементом управління виробництвом і процесами обігу ресурсів. Незважаючи на значні успіхи, досягнуті у сорері логістики, погляди вчених щодо тлумачення даного поняття досить різняться, що й визначає актуальність даного дослідження.

Дослідженням теоретичних та практичних аспектів логістики займаються такі вчені та науковці України: Л.В. Балабанова, Г.І. Брітченко, М.Ю. Григорак, М.С. Дороніна, А.Г. Кальченко, В.Л. Пілюшенко, О.М. Тридід, Н.I. Чухрай, О.О. Шубін, Л.В. Фролова та ін. Серед зарубіжних вчених питанням логістики присвятили свої праці: П. Друкер, Дж. Ландлеу, Г. Пфоль, К. Кльозе, Л.Б. Міротіна, Б.А. Анікіна, Д.Дж. Бауерсокс, Д.Дж. Клосс, А.Г. Белоусов, Д.В. Стаханов, А.М. Гаджинський, М.П. Гордон та ін.

Мета статті. Головною метою цієї роботи $\epsilon$ аналіз логістики як інструменту підвищення конкурентоспроможності підприємства.

Виклад основного матеріалу дослідження. Жорсткі умови конкурентної боротьби вимагають від підприємств застосування нових підходів до планування та управління рухом товарних потоків від виробника готової продукції до споживача, заснованих на принципах логістики, а зростання іiі ролі в забезпеченні конкурентоспроможності підприємств зумовило необхідність перегляду підходів визначення цього терміну [6].

По-перше, логістика є частиною загальної теорії управління, але виокремлюється з неї своєю специфікою, яка полягає в управлінні різноманітними потоковими процесами, що мають просторово-часову послідовність. 3 чого випливає висновок, що об'єктом її використання може бути будь-яка діяльність, де сукупність процесів чи подій має альтернативну послідовність у просторі та в часі й розглядає багато варіантів її організації та управління за певними критеріями.
По-друге, особливістю логістики є ї̈ здатність не тільки керувати потоковими процесами, а й забезпечувати організацію раціонального управління ними з метою виявлення прихованих резервів управління, головним чином у вигляді додаткових доходів і прибутку підприємства та інших ринкових структур. По-трете, особливістю логістики $€$ її призначення для реорганізації форм і методів управління потоковими процесами 3 метою виявлення та використання додаткових резервів за рахунок продуктивних фракторів і джерел. Це є найбільш характерним для еволюційно налагодженої ринкової економіки розвинених країн.

Логістику розглядають як сферу наукової діяльності, яка спрямована на створення системи виробничо-комерційних взаємовідносин на мікро-, мезо-, макрорівнях на принципах інтеграції та оптимізації матеріальних (матеріальні ресурси, напівфабрикати, готова продукція), інформаційних (паперова чи електронна документація), фрінансових (фінансові ресурси), сервісних (послуги транспортних підприємств, експедиторських компаній, гуртових та роздрібних посередників тощо), інноваційних (наукових ідей, розробок), кадрових i інвестиційних потоків у коротко- та довгостроковому періодах з метою забезпечення максимізації прибутку, збільшення частки ринку та досягнення довгострокових конкурентних переваг [5].

3 цього можна зробити висновок, що логістика є науково-практичним інструментом спільного господарювання багатьох економічно самостійних ринкових структур, що дозволяє досягти раціональної організації потокових процесів, які відбуваються в просторово-часовій послідовності, з метою виявлення та реалізації потенційних резервів управління й одержання додаткових доходів і прибутку цими структурами переважно за рахунок суспільно-корисних, головним чином виробничих, факторів і джерел. Саме концепція логістики містить у собі значні резерви економії часу та оптимізації витрат на виконання логістичних операцій [7]. Досвід провідних зарубіжних країн доводить високу ефективність логістики в отриманні стійких конкурентних переваг. Завдяки їй підприємства забезпечують необхідний рівень обслуговування кінцевого споживача, надаючи йому при цьому певні додаткові користі (цінності). Ці додаткові цінності можуть стосуватися 
і еластичності поставок щодо величини партії, і еластичності щодо умов оплати, і еластичності щодо термінів та місця виконання замовлення.

Ефективність підприємства і його конкурентоспроможність прямо пов'язані з ефективністю системи контролю за операційними витратами. Тенденція до зростання витрат підприємств призводить до необхідності аналізу логістичної діяльності 3 метою виявлення джерел можливої економії. Необхідність зниження логістичних витрат пов'язана із підвищення цін на продукцію, з одного боку, і обмеженням розмірів ринків збуту, що не дозволяє збільшити обсяг виробництва продукції, - 3 іншого [7].

Простий шлях скорочення, до якого на практиці сходяться більшість програм 3 мінімізації витрат, може призвести до послаблення позиції підприємства. Логістичні витрати на підприємстві зазвичай складають 5-35\% від обсягів продажу залежно від виду бізнесу, географічного розміщення підприємства та співвідношення вагових і цінових характеристик матеріальних ресурсів та готової продукції. Витрати на логістику, як правило, складають одну 3 найбільших частин витрат, пов'язаних з веденням бізнесу, поступаючись лише витратам на сировину та матеріали у виробництві або собівартості реалізованої продукції в оптовій та роздрібній торгівлі.

Аналіз структур логістичних витрат показує, що найбільшу частку в них займають витрати на управління запасами (20-40\%), транспортні витрати (15-35\%) та адміністративні витрати (9-14\%) [2].

Загалом, основною концепцією, що описує ефрективність логістичних витрат, є концепція загальних витрат або повної вартості, яка була введена Л. Говардом, Д. Каллітоном і Д. Стілом. Вони показали, як підхід з позиції загальних витрат виправдовує високі затрати на логістичні операції. Суть цієї концепції полягає в тому, що, якщо витрати на якісне та вчасне обслуговування споживачів дозволяють зменшити або зовсім усунути інші витрати (зокрема на складування і зберігання запасів), то паралельно відбувається зниження загальних витрат підприємства. Основні переваги управління логістичними витратами як засобом підвищення ефективності діяльності підприємства є виробництво конкурентоспроможної продукції за рахунок нижчих витрат i, відповідно, зниження ціни одиниці продукції; наявність якісної та реальної інфрормації про логістичні витрати окремих видів продукції; надання об'єктивних даних для прийняття обгрунтованих і едективних управлінських рішень.

Таким чином стає все більш очевидним те, що конкурентна перевага виходить із здатності до комбінування мережі пов'язаних організацій, яка в наш час отримала назву логістичного ланцюга поставок. Це фундаментальне зрушення від традиційного погляду на бізнес з точки зору окремого підприємства. До того ж у сучасних економічних умовах ринки стають все більш мінливими i, отже, менш передбачуваними. Таким чином потреба в адаптивному реагуванні зростає. Основною рисою сучасного бізнесу є ідея про те, що конкурують не підприємства, а ланцюги поставок підприємств (постачальницько-збутові ланцюжки), а успіх або провал ланцюгів поставок визначається на ринку кінцевим покупцем [10]
Отримання покупцем потрібного продукту в потрібному місці у потрібний час - не тільки вимога процвітання (домогтися конкурентного успіху), але і ключовий момент виживання на ринку. Отже, задоволення потреб покупців і знання ринку є вирішальними елементами для розгляду, коли підприємство намагається виробити нову логістичну стратегію. Тільки при повному розумінні потреб і обмежень ринку підприємство може зробити спробу розробити стратегію, яка задовольнить як учасників логістичного ланцюга, так і кінцевих споживачів (покупців). Ініціативи щодо поліпшення показників логістичного ланцюга спрямовані на зведення попиту та пропозиції шляхом зниження витрат і водночас більш повного задоволення вимог покупця. Це обумовлює скорочення невизначеності у логістичному ланцюзі наскільки це можливо, забезпечення передбачуваності попиту для попередніх ділянок логістичного ланцюга.

Отже, підприємство має змиритися із невизначеністю, але необхідно виробити стратегію, яка все ж дозволить зводити попит і пропозицію. Значний інтерес останнім часом було виявлено до концепції «чіткого виробництва» і більш широкої концепції «чіткого підприємства». У контексті нашої статті пояснимо, що концепція «чіткості» досить ефрективно застосовується в умовах відносної стабільності, передбачуваності попиту і низької невизначеності. Навпаки, в умовах, де попит і потреби покупців сильно варіюються, виникає потреба у високому рівні адаптивності логістичного ланцюга. У межах дослідження можливих варіантів застосування концепцій необхідно, на наш погляд, показати різні умови, за яких ці концепції можна комбінувати, забезпечуючи високу конкурентоспроможність ланцюга, здатну перемагати в мінливому і конкурентному середовищі. Для початку ми вкажемо на важливі відмінності у двох концепціях, а також, як одна 3 них може вигравати при впровадженні іншої. Як адаптивність, так і чіткість висувають вимоги високої якості продукту [8].

Вони також вимагають мінімізації загального часу задоволення потреби, яке визначається як час від подачі заявки клієнтом до доставки товару. Загальний час виконання має бути мінімізовано для забезпечення адаптивності, оскільки попит сильно варіативний і важко передбачуваний. Якщо ланцюг має довгі періоди доставки, то підприємство не може достатньо швидко реагувати на потреби, щоб завойовувати ринок. До того ж, ефрективне реструктурування скорочення операційних циклів завжди призводить до скорочення виробничих витрат і підвищення продуктивності. Терміни доставки необхідно скоротити в чіткому виробництві відносно зайвого часу доставки як непотрібних витрат, а чіткість передбачає усунення всіх непотрібних (зайвих) витрат. Суть різниці між чіткістю і адаптивністю щодо забезпечення додавання вартості для покупця в тому, що рівень обслуговування (доступність) - критичний показник для адаптивності, в той час, як витрати і низька ціна продажу тісно пов'язана із чіткістю. Тим не менше, там, де концепція скорочення загального часу циклу при ефективному впровадженні є достатньою умовою досягнення чіткого виробництва, це лише одна з умов досягнення адаптивного постачання. 
Висновки. Таким чином, використання логістики в господарській діяльності ринкових структур в умовах рефрормування економіки України не може обмежитися лише раціоналізацією іх систем управління, а повинна супроводжуватися паралельним перетворенням їх у системи. У результаті ефект від її використання набагато перевищить додаткову вигоду суб'єктів господарювання від раціональної (оптимальної) організації управління іх потоковими процесами. Розгляд потенціалу логістики та її складників обумовлено потребою розробки механізму оцінки можливості застосування сучасних економічних підходів в практичній діяльності підприємства. Оцінка їі потенціалу дасть змогу виявити приховані резерви в розвитку підприємства, а отже - збільшити віддачу від більш обгрунтованого застосування сучасних економічних інструментів, підвищити ефективність логістичних процесів та отримати такий економічний ефект, як скорочення витрат і часу у сорерах виробництва та обігу.

\title{
Список літератури:
}

1. Иванов Д.А. Логистика Стратегическая кооперація / Д.А. Иванов. - М.: Вершина, 2006. - 176 с.

2. Ковалев К.Ю. Логистика в розничной торговле: как построить эффрективную сеть / К.Ю. Ковалев, С.А. Уванов, П.Е. Щеглов. - СПб.: Питер, 2007. - 272 с.

3. Науменко M.О. Маркетинг: навчальний посібник / М.О. Науменко, В.І. Пеньков, Б.А. Рудов, Н.Г. Гончаренко. X.: ABBMBCУ, 2010. - 232 c.

4. Соколовський С.А. Управління якістю виробництва та обслуговування: навчальний посібник / С.А. Соколовський, С.П. Павлов, М.В. Черкашина М.О. Науменко, Є.М. Грабовський. - Харків: НАНГУ, 2015. - 264 с.

5. Михальчук Л.Ю. Аналіз впливу логістичних витрат на ефективність функціонування логістичної системи / Л.Ю. Михальчук, М.О. Микитин // Вісник Хмельницького національного університету. - 2009. - № 1. - С. 30-34.

6. Дикань В.Л. Забезпечення конкурентоспроможності підприємств: підручник / В.Л. Дикань, Ю.Т. Боровик, О.М. Полякова, Ю.М. Уткіна. - Х.: УкрДАЗТ, 2012. - 415 с.

7. Каличева Н.Є. Логістичні підходи, як основа раціональної організації виробничого процесу на підприємстві / Н.Є. Каличева, В.О. Маслова // Вісник економіки транспорту і промисловості. Збір наук. праць - Харків: УкрДАЗТ, 2014. - № 47. - С. 83-86.

8. Каличева Н.Є. Роль транспортно-логістичних систем у забезпеченні стійкого розвитку економіки / Н.С. Каличева // Вісник економіки транспорту і промисловості: збірник наукових праць. - Харків: УкрдУЗТ, 2017. - № 58. - С. 103-109.

Бессонова А.В., Лавренюк Е.М., Середницкая Л.П.

Винницкий торгово-экономический институт

Киевского национального торгово-экономического университета

\section{ЛОГИСТИКА КАК ИНСТРУМЕНТ ПОВЫШЕНИЯ КОНКУРЕНТОСПОСОБНОСТИ ПРЕДПРИЯТИЯ}

\author{
Аннотация \\ ние затрат и времени в сферах производства и обращения. \\ логистическая система, конкурентоспособность. \\ Bessonova A.V., Lavrenyuk E.M., Serednitskaya L.P. \\ Vinnitsa Trade and Economic Institute \\ Kyiv National University of Trade and Economics

\section{LOGISTICS AS A TOOL TO IMPROVE COMPETITIVENESS OF THE ENTERPRISE}

В статье исследовано логистику как инструмент повышения конкурентоспособности предприятия в современных условиях хозяйствования. Проанализированы особенности влияния логистических издержек на эффективность функционирования логистической системы в условиях функционирования развитой экономики. Определены и обоснованы современные экономические инструменты, повышение эффективности логистических процессов и получения такого экономического эффекта, как сокраще-

Ключевые слова: логистика, расходы, эффективность, логистический менеджмент, предприятие,

\section{Summary}

The article examines logistics as a tool to improve the competitiveness of enterprises in the current economic conditions. Analyzed the features of the impact of logistics costs on the efficiency of the logistics system in a functioning economy. Modern economic tools, increasing the efficiency of logistic processes and obtaining such an economic effect as reducing costs and time in the areas of production and circulation are identified and justified.

Keywords: logistics, costs, efficiency, logistics management, enterprise, logistics system, competitiveness. 